\title{
Harmful Phytoplankton Blooms and Fish Mortality in a eutrophicated reservoir of Northeast Brazil
}

\author{
Naithirithi Tiruvenkatachary Chellappa ${ }^{1}$, Sarah Laxhmi Chellappa ${ }^{2}$ and Sathyabama \\ Chellappa ${ }^{1}$ \\ ${ }^{1}$ Centro de Biociências, Departamento de Oceanografia e Limnologia; Universidade Federal do Rio Grande do \\ Norte; Praia de Mãe Luíza, s/n; chellappa@dol.ufrn.br; 59014-100; Natal-RN - Brasil. ${ }^{2}$ Centro da Ciência da \\ Saúde; Universidade Federal do Rio Grande do Norte; Avenida Gustavo Cordeiro de Farias; s/ $n$, Petrópolis; \\ 59010-180; Natal - RN - Brasil
}

\begin{abstract}
The aim of this work was to study the eutrophication in the tropical freshwater ecosystems and the consequent cyanobacterial bloom formation and economical damage to fisheries and harmful effects to public health. Mass fish mortality due to toxin producing cyanobacterial blooms was registered during December 2003 in Marechal Dutra Reservoir, Acari/RN, Northeast Brazil. Phytoplankton and fish samplings were carried out on alternate days during the episode of fish mortality and monthly during January to June 2004. The cyanobacterial toxin was identified and quantified from the seston samples and liver of the dead fishes using the standard HPLC method. The results indicated that the toxic blooms of Cylindrospermopsis raciborskii and Microcystis aeruginosa were persistent for two weeks and represented $90 \%$ of the phytoplankton species assemblages. The lethally affected fishes were Oreochromis niloticus, Plagioscion squamosissimus, Cichla monoculus, Prochilodus brevis, Hoplias malabaricus and Leporinus friderici. The microcystin levels varied from 0.07 to $8.73 \mu \mathrm{g} \mathrm{L}^{-1}$ in the seston samples and from 0.01 to $2.59 \mu \mathrm{g} \mathrm{g}^{-1}$ in the liver samples of the fishes during the bloom period.
\end{abstract}

Key words: Harmful algal blooms, anthropogenic activity, fish mortality, reservoir, public health

\section{INTRODUCTION}

The semi-arid freshwater ecosystems of northeast Brazil frequently encounter water level fluctuations because of the recurrence of extended drought, irregular rainfalls and high temperatures, with evaporation rates outstripping the yearly precipitation. The seasonality of the freshwater ecosystems of this region is defined by the short spells of intense rainfall (March to July) coupled with an extended dry period throughout the rest of the year (Bouvy et al., 2000; Dellamano-Oliveira et al., 2003; Chellappa and Chellappa, 2004; Moura et al., 2007).

Eutrophication in the tropical freshwater ecosystems is a process that triggers the sporadic occurrence of the toxin producing phytoplankton blooms, which results in economical damage to the fisheries and harmful effects to the public health (Falconer, 2001; Best et al., 2002). The occurrence of the cyanobacterial blooms in the freshwater is usually accompanied by both the

\footnotetext{
* Author for correspondence
} 
toxin and non-toxin producing species (Baker and Humpage, 1994). Cyanotoxins are responsible for the intoxication in the wild and domestic animals, contamination of the water for the human consumption, fish mortality and elimination of other aquatic biota (Carmichael 2001). The commonly encountered toxin producing species of cyanobacteria include Anabaena circinalis, Aphanizomenon flos-aquae, Microcystis aeruginosa, and Cylindrospermopsis raciborskii (Azevedo et al., 1994; Lagos et al., 1999).

In Brazil, the toxic blooms of the cyanobacteria have been reported in the coastal lagoons (Azevedo, 1994; Porfirio et al., 1999; Magalhães et al., 2001; Lagos et al., 1999), in the estuaries (Matthiensen et al., 1999), and in the reservoirs (Bouvy et al., 2000; Chellappa et al., 2000). It has been reported that the presence of the microcystin toxin from the blooms of Microcystics aeroginosa in the water storage tank of a haemodialysis clinic resulted 53 deaths in Caruaru city, in the state of Pernambuco (Jochimson et al., 1998). This episode reinforced the importance of the toxic blooms on the public health and was the starting point of intense monitoring study on the water quality of the reservoirs and detection of the toxic cyanobacterial bloom in order to provide early warning signals to the reservoir management programmes. Previous studies conducted in the Marechal Dutra reservoir reported cyanobacterial bloom formation and fish kill episodes in 2000, when Microcystis aeruginosa grew exponentially and caused mass mortality of the fishes (Chellappa et al., 2000). Ever since the reservoir water has shown persistent symptoms of the eutrophication, with the dominance of the cyanobacteria species and no further incidence of fish mortality (Chellappa et al., 2000).

The purpose of this study was to report an episode of mass fish mortality associated with the toxin producing cyanobacteria and its impact on the reservoir fish culture.

\section{MATERIAL AND METHODS}

\section{Study Area}

The Marechal Dutra Reservoir is located in Acari city and situated at a distance of $223 \mathrm{Km}$ of Natal, capital of the state of Rio Grande do Norte, Brazil. This reservoir is within the coordinates of $6^{\circ} 26^{\prime} 11^{\prime \prime} \mathrm{S}$ and $36^{\circ} 36^{\prime} 17^{\prime \prime} \mathrm{W}$ and was built in 1958 by damming the River Acauã, pertaining to the Piranhas-Assu hydrographical basin of the semi-arid northeast zone of Rio Grande do Norte. It has a storage capacity of $40,000,000 \mathrm{~m}^{3}$, with a drainage area of $2400 \mathrm{Km}^{2}$. It is a shallow reservoir with an average depth of $5.2 \mathrm{~m}$ and an estimated maximum depth of $21 \mathrm{~m}$. The time of water residence was 4.2 years during the study period, with oscillations according to the flux and drainage of the water. The reservoir water is used mainly for human consumption, irrigation, fisheries and cage fish culture in the shallow regions of this reservoir by the local fishermen.

\section{Sampling and Analysis}

The sampling was carried out from December 2003 to June 2004, which included both dry (December to March) and wet seasons (April to June). The study period coincided with the intensification of cage culture practices in the reservoir. Throughout the intense period of bloom formation and fish kill events, which were during the first 15 days of December 2003, the collections were made on the alternate days, thus a total of eight samples. The phytoplankton samples that were carried out from January to June 2004 were conducted on a monthly basis. The collections were carried out at four stations in the reservoir near to the cage cultures from 9:00h to $11: 00 \mathrm{~h}$. The samples were obtained at the surface level $(0 \mathrm{~m})$ and from the surface water at the depths of 4 , 8 and $11 \mathrm{~m}$. The physical-chemical parameters such as, temperature, $\mathrm{pH}$, dissolved oxygen and electrical conductivity of the water were measured using a Multi-parameter Kit and the inorganic nutrients such as, nitrate, phosphate and ammonia were analyzed (Goltermann et al., 1978).

The phytoplankton analysis was carried out using the samples of $1 \mathrm{~L}$ of water fixed in lugol-iodine solution and the quantitative enumerations were made using inverted microscopy (Lund et al., 1958). The plankton samples were collected from net tows in the water column using a $20 \mu \mathrm{m}$ mesh net and the materials were preserved in acetic acid-lugol to determine the species composition. The identification was carried according to Weah and Sheath (2003). The seston samples were collected and filtered through the Whatman GF/C acid-washed glass fiber filters and frozen at $-20^{\circ} \mathrm{C}$ until subsequent analysis. The cyanotoxins were analyzed by the High Performance Liquid Chromatography technique (Krishnamurthy et al., 1986). 
The microcystin extraction from the seston samples was carried out using the methanol: butanol: water $(20: 5: 75 \mathrm{v} / \mathrm{v})$ solution. Afterwards, the extract was centrifuged and the supernatant was evaporated to $30 \%$ of its initial volume, with the resultant extract passed in a $\mathrm{C}-18$ cartridge (Bond Elut C-18 varian). The sample was eluted from the cartridge with $20 \mathrm{ml}$ of de-ionized water, methanol $20 \%$ and methanol $100 \%$, respectively. The $100 \%$ methanol fraction was evaporated to dryness, resolubilized in $1 \mathrm{ml}$ methanol $(50 \%)$ and filtered in nylon filter $(0.45 \mu \mathrm{m})$. The microcystin identification and quantification was carried out through HPLC, with a U.V./Vis detector, SOD-10 A, LC-10aS bombs and CR6A integrator, comparing the absorption spectrum with the Microcystin-LR standard.

The analyses were held in isocratic conditions and reverse level, using a semi-preparative column (Supercosil LVC-18, 5, 25cm x 10mm), with a mobile phase of acetonitril and ammonium acetate $(20 \mathrm{mM})$, pH $5.0(28: 72 \mathrm{v} / \mathrm{v})$, with $1 \mathrm{ml} \mathrm{Min}^{-1}$ flow, loop of $100 \mu \mathrm{L}$ and $\mathrm{UV}$ detector set at $238 \mathrm{~nm}$ (Krishnamurthy et al., 1986). Chlorophyll- $a$ concentrations were analyzed using acetone extract and corrected to phaeophytin (Goltermann et al., 1978).

Fish sampling in the study area was carried out using the dragnets of different mesh sizes, varying from 24 to $100 \mathrm{~mm}$, and other types of fishnets, such as, cast nets, hand nets and hook and line. The fishes were identified, numbered, labeled and the biometric data were registered in the Ichthyology Laboratory of the Federal University of Rio Grande do Norte, Brazil.

\section{RESULTS}

Table 1 presents the summary of the physical and chemical characteristics of a vertical profile of the reservoir waters during dry and wet periods. The $\mathrm{pH}$, bicarbonate alkalinity and dissolved oxygen concentrations gradually declined according to the depth, being highest at surface and lowest at $11 \mathrm{~m}$. The temperature did not exhibit drastic variation in both dry and wet seasons, as well as in the vertical profile

Table 1 - Mean values in relation to depth profile, physical and chemical variables and significance levels in Marechal Dutra reservoir, Acari/ RN, during 2003-2004.

\begin{tabular}{|c|c|c|c|c|c|c|c|c|c|c|c|c|}
\hline Parameters & $\begin{array}{l}\text { Dry } \\
\text { Om }\end{array}$ & $\begin{array}{l}\text { Dry } \\
4 m\end{array}$ & $\begin{array}{l}\text { Dry } \\
8 m\end{array}$ & $\begin{array}{c}\text { Dry } \\
\mathbf{1 1} \\
\text { m }\end{array}$ & $\begin{array}{c}\text { Dry } \\
\text { F }\end{array}$ & $\begin{array}{c}\text { Dry } \\
\text { P }\end{array}$ & $\begin{array}{l}\text { Wet } \\
\text { Om }\end{array}$ & $\begin{array}{l}\text { Wet } \\
\mathbf{4 m}\end{array}$ & $\begin{array}{l}\text { Wet } \\
8 \mathrm{~m}\end{array}$ & $\begin{array}{l}\text { Wet } \\
\text { 11m }\end{array}$ & $\begin{array}{c}\text { Wet } \\
\text { F }\end{array}$ & $\begin{array}{c}\text { Wet } \\
\text { P }\end{array}$ \\
\hline $\mathrm{pH}$ & 9.2 & 8.7 & 8.6 & 8.4 & 62.7 & 0.005 & 8.5 & 8.2 & 7.6 & 7.5 & 69.7 & 0.005 \\
\hline Bicarbonate $\left(\mathrm{mgL}^{-1}\right)$ & 131 & 135 & 137 & 138 & 60.91 & 0.001 & 125 & 101 & 114 & 127 & 17.12 & 0.01 \\
\hline Carbonate $\left(\mathrm{mgL}^{-1}\right)$ & 79 & 39 & 35 & 33 & 12.14 & 0.001 & 7 & 13 & 0 & 0 & 40.91 & 0.001 \\
\hline Conductivity $\left(\mu \mathrm{scm}^{-1}\right)$ & 860 & 931 & 855 & 659 & 17.16 & 0.03 & 225 & 221 & 22 & 220 & 77.19 & 0.03 \\
\hline $\mathrm{T}\left({ }^{\circ} \mathrm{C}\right)$ & 27 & 27 & 28 & 26 & 8.90 & 0.69 & 30 & 29 & 29 & 29 & 38.51 & 0.71 \\
\hline$\% \mathrm{O}_{2}$ & 85.1 & 65.1 & 26.0 & 16.8 & 28.91 & 0.001 & 89.8 & 66.5 & 34.1 & 18.2 & 9.26 & 0.008 \\
\hline $\mathrm{DO}\left(\mathrm{mgL}^{-1}\right)$ & 6.4 & 5.1 & 2.4 & 1.3 & 21.98 & 0.000 & 6.4 & 5.0 & 2.3 & 1.2 & 19.18 & 0.008 \\
\hline Total $\mathrm{P}\left(\mathrm{mgL}^{-1}\right)$ & 0.66 & 0.64 & 0.70 & 0.65 & 5.26 & 0.000 & 0.74 & 0.79 & 0.85 & 0.76 & 11.98 & 0.04 \\
\hline Ammonia $\left(\mathrm{mgL}^{-1}\right)$ & 0.17 & .21 & 0.34 & 0.48 & 7.98 & 0.04 & 0.14 & 0.15 & 0.18 & 0.64 & 19.75 & 0.02 \\
\hline Total N $\left(\mathrm{mgL}^{-1}\right)$ & 0.61 & 0.71 & 0.66 & 0.91 & 12.75 & 0.02 & 1.09 & 0.85 & 0.97 & 0.89 & 3.90 & 0.69 \\
\hline
\end{tabular}

High oxygen values were encountered at the surface with high oxygen saturation and reduced hypolimnetic oxygen values as low as $16 \%$. The conductivity values showed a slight variation along the vertical, with an increase in the surface water during the dry season. The inorganic nutrients were high indicating the degree of eutrophication of the reservoir during the study period. The presence of toxin producing cyanobacterial species, such as, $M$. aeruginosa and $C$. raciborskii were observed during the fish kills. The lethally affected 
fishes were tilapia, Oreochromis niloticus, Plagioscion squamosissimus, Cichla monoculus, Prochilodus brevis, Hoplias malabaricus and Leporinus friderici, besides the freshwater shrimp, Macrobrachium amazonicum. Table 2 shows the phytoplankton composition during the study period and the reduced species diversity. A total of $90 \%$ phytoplankton composition was composed of cyanobacterial species during the bloom period. The toxin producing species, $M$. aeruginosa and $C$. reciborskii alternated dominance during the bloom formation. The first four days of the intense bloom period had a higher number of filaments of $C$. raciborskii, which was gradually substituted by $M$. aeruginosa, and this alternate domination became a characteristic feature.

Table 2 - Phytoplankton species composition in Marechal Dutra reservoir during 2003-2004.

\begin{tabular}{|c|c|c|c|c|}
\hline \multirow[t]{2}{*}{ Phytoplankton Species (dry season) } & \multicolumn{4}{|c|}{ Vertical profile } \\
\hline & $\mathbf{0 m}$ & $4 \mathrm{~m}$ & $\mathbf{8 m}$ & $11 \mathrm{~m}$ \\
\hline \multicolumn{5}{|l|}{$\overline{\text { Cyanophyceae }}$} \\
\hline Cylindrospermopsis raciborskii (Woloszinska)Sennayya and Subba Raju & $\mathrm{x}$ & $\mathrm{x}$ & $\mathrm{x}$ & $\mathrm{x}$ \\
\hline Gloeocapsa alpicula (Lyng.) Bornet and Flahaulf & $\mathrm{x}$ & $\mathrm{x}$ & $\mathrm{x}$ & \\
\hline Lyngbya major Menegh & $\mathrm{x}$ & & & $\mathrm{x}$ \\
\hline Microcystis aeruginosa Küetzing & $\mathrm{x}$ & $\mathrm{x}$ & $\mathrm{x}$ & $\mathrm{x}$ \\
\hline Oscillatoria articulata Gardner & & $\mathrm{x}$ & & $\mathrm{x}$ \\
\hline Oscillatoria lacustris Lemm. & $\mathrm{x}$ & $\mathrm{x}$ & & \\
\hline Oscillatoria limmetica (Klèb.) Geitler & $\mathrm{x}$ & $\mathrm{x}$ & $\mathrm{x}$ & $\mathrm{x}$ \\
\hline Pseudanabaena catenata Laut. & $\mathrm{x}$ & & $\mathrm{x}$ & \\
\hline \multicolumn{5}{|l|}{ Bacillariophyceae } \\
\hline $\begin{array}{l}\text { Aulacoseira granulata (Ehrenberg) Simonsen } \\
\text { Chlorophyceae }\end{array}$ & $\mathrm{x}$ & $\mathrm{x}$ & $\mathrm{x}$ & $\mathrm{x}$ \\
\hline $\begin{array}{l}\text { Coelastrum cambricum Archer } \\
\text { Nephrocytium lunatum West. }\end{array}$ & $\mathrm{x}$ & $\mathrm{x}$ & $\mathrm{x}$ & $\begin{array}{l}\mathrm{x} \\
\mathrm{x}\end{array}$ \\
\hline \multicolumn{5}{|l|}{$\begin{array}{l}\text { Phytoplankton Species (Wet Period) } \\
\text { Cyanobacteria }\end{array}$} \\
\hline Chroococcus dispersus (V. Keiss) Lemm. & $\mathrm{x}$ & & & \\
\hline Chroococcus decorticans (A. Br.) & $\mathrm{x}$ & $\mathrm{x}$ & $\mathrm{x}$ & $\mathrm{x}$ \\
\hline Chrooccocus giganteus West. & $\mathrm{x}$ & $\mathrm{x}$ & $\mathrm{x}$ & $\mathrm{x}$ \\
\hline Chroococcus varius A. Braun & $\mathrm{x}$ & $\mathrm{x}$ & & $\mathrm{x}$ \\
\hline Gloeocapsa alpicula (Lyng.) Bornet and Flahaulf & $\mathrm{x}$ & $\mathrm{x}$ & $\mathrm{x}$ & \\
\hline $\begin{array}{l}\text { Microcystis aeruginosa Küetzing } \\
\text { Bacillariophyceae }\end{array}$ & $\mathrm{x}$ & $\mathrm{x}$ & $\mathrm{x}$ & $\mathrm{x}$ \\
\hline $\begin{array}{l}\text { Aulacoseira granulata (Ehrenberg) Simonsen } \\
\text { Chlorophyceae }\end{array}$ & $\mathrm{x}$ & $\mathrm{x}$ & $\mathrm{x}$ & $\mathrm{x}$ \\
\hline Coelastrum cambricum Archer & $\mathrm{x}$ & $\mathrm{x}$ & $\mathrm{x}$ & $\mathrm{x}$ \\
\hline Pandorina morum Bory & $\mathrm{x}$ & $\mathrm{x}$ & $\mathrm{x}$ & \\
\hline Scendesmus quadricauda (Turp) Brébisson & $\mathrm{x}$ & $\mathrm{x}$ & $\mathrm{x}$ & \\
\hline
\end{tabular}

During December 2003, the combined blooms of C. raciborskii and $M$. aeruginosa produced hepatotoxins. Results of the seston and fishes liver samples indicated the presence of microcystin and the highest concentration was observed on the seventh day of the samples The ichthyotoxin showed increase in concentration until it reached the maximum in the liver in the first week and 
decreased gradually during the second week of bloom formation (Fig. 1).

Results of chlorophyll biomass indicated that it doubled from the first to the seventh day (exponential phase) and collapsed after the seventh day of the bloom formation (collapse phase). The values of chlorophyll a and its degraded component, phaeophytin, were inversely related (Fig.2).
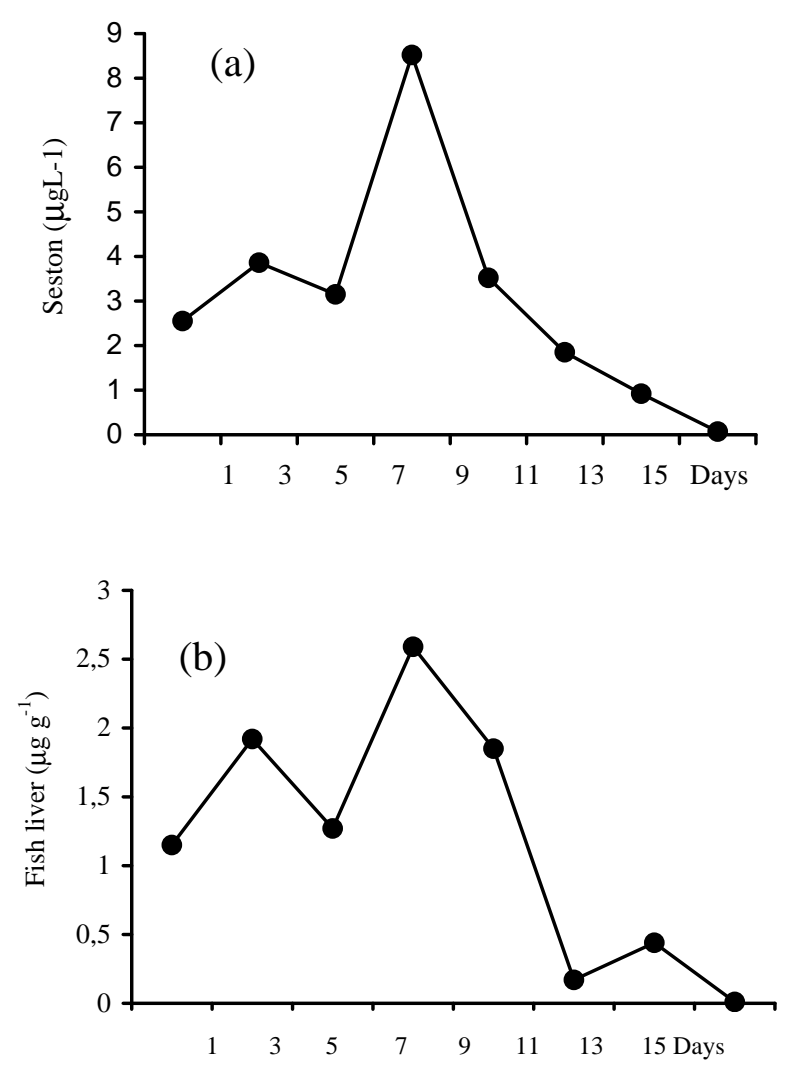

Figure 1 - Microcystin levels in the seston (a) and in the fish liver (b) during the bloom period.

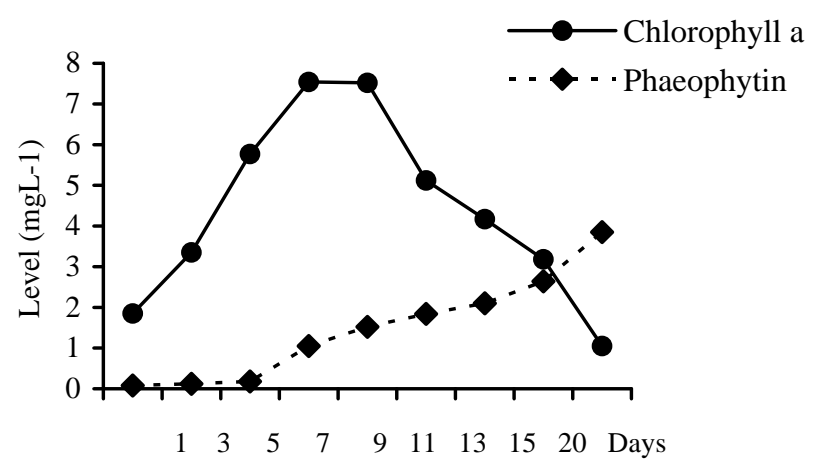

Figure 2 - Levels of Chlorophyll $a$ and phaeophytin during December 2003. 
The results of the one-way ANOVA between the vertical profile and the physical and chemical variables, during both dry and wet seasons are shown in Table 3. The icthyofauna of the reservoir was composed of native fish species as Prochilodus brevis (6\%), Hypostomus pusarum (4\%), Synbranchus marmoratus (3\%), Hoplias malabaricus (2\%), and introduced fish species, such as, Oreochromis niloticus (44\%), Plagioscion squamosissimus (22\%), Cichla monoculus (9\%), Leporinus friderici (6\%) and Astronotus ocellatus $(4 \%)$.

The composition of fish fauna of the Marechal Dutra reservoir revealed $O$. niloticus as the dominant component. Mass killing of the diverse species of the fish community in December 2003 coincided with the heavy toxin producing bloom of $M$. aeruginosa and $C$. raciborskii in the reservoir. In the current study, the liver samples from $O$. niloticus and $P$. squamosissimus were contaminated with the hepatotoxins, which caused the mass mortality of the fishes.

\section{DISCUSSION}

The results from the phytoplankton species composition of the eutrophicated impounded waters of the Marechal Dutra Reservoir, Acari, Rio Grande do Norte, recorded in this study demonstrated an overwhelming dominance of the cyanobacteria during both dry and wet seasons. The water quality depends on a variety of biotic and abiotic factors, seasonality, as well as anthropogenic activities, such as, the dam construction and increased soil erosion. As a result, the eutrophication in the water bodies frequently occurs. The development of a bloom is based on the assumption that a species or a species assembling becomes dominant in the density by the possessing mechanisms that enable a competitive advantage in comparison to other species present in the water body (Codd, 2000). The cyanobacteria have some characteristics that possibly explain its success under certain environmental factors, such as macronutrients like nitrogen and phosphorus (Reynolds et al., 2000), temperature, $\mathrm{pH}$, and light (Lee and Rhee, 1999). In the present study, the total nitrogen and total phosphorus increased considerably during the wet season, probably due to the increased turbidity and the artificial feeds added to the maintenance of the cage culture of the fishes suspended in the reservoir. Therefore, the anthropogenic stresses may result in the modifications of the physical and chemical water composition and phytoplankton composition, particularly in favor of the cyanobacterial population in the dry season and chlorophycean population in the wet season.

In relation to the chlorophyll/phaeophytin concentrations, high chlorophyll a and low phaeophytin degraded pigments concentrations were observed during the first two weeks of December 2003, which should be addressed to the intense bloom formation. During January to June 2004, the concentration of these substances could be attributed to the turbid condition of the water, which was likely due to the presence of large suspended organic matter, particularly during the wet season.

Although the eutrophication has been recognized as worldwide growing concern, only recently the cyanobacterial toxins have been studied in detail and widely recognized as a public health issue (Jochimson et al., 1998; Chorus and Bartram, 1999). The cyanobacterial dominance in the eutrophicated freshwaters has been studied since 1990 in the state of Rio Grande do Norte (Chellappa and Chellappa, 2004). The need for toxin analysis originated from the association of fish mortality with the toxic blooms of $M$. aeruginosa, which occurred in Marechal Dutra reservoir of Rio Grande do Norte in January 2000 (Chellappa et al., 2000). This study registered the presence of microcystin and its coincidence with the bloom of $C$. raciborskii and $M$. aeruginosa, thus suggesting the dominance of potential toxin producing species in this reservoir. The production of saxitoxin, microcystin, nodularin and cylindropsermopsin has been observed both in the natural populations and in the unialgal cultures of the toxic species (Falconer, 2001; Jochimsen et al., 1998; Lagos et al., 1999). A previous study has observed the production of saxitoxin by Aphanizomenon, Anabaena, Lyngbya and Cylindrospermopsis from the unialgal cultures, with dominance of C-toxins, neoSTX and GTX, respectively (Chorus and Bartram, 1999). A similar such trend in relation to the production of hepatotoxic microcystin was encountered in this study.

The maximum level for the microcystin accepted in the potable water is $1 \mu \mathrm{g} \mathrm{L}^{-1}$ in Brazil (Azevedo et al., 1994). However, the results revealed the microcystin levels as high as $8.73 \mu \mathrm{g} \mathrm{L}^{-1}$ in the 
seston materials of the reservoir, thus endangering the consumer's health.

The reservoirs with the planktivorous fishes that are not controlled by the piscivorous fish communities have higher macrozooplankton biomass. The fish assemblage composition effects may cascade down the food web in the reservoirs, although bottom-up and top-down effects may be unsymmetrical in character. For the reservoirs with balanced fish assemblages, it is expected that the efficiency of the nutrient transference from the bottom up in the trophic web should diminish from algae to piscivorous fishes (Quirós and Boveri, 1999).

In the study reservoir, the fish community composition is usually dependent on the human actions, such as the fish introductions and stocking densities by the local fisherman. The presence of the facultative planktivorous fish that depend on the benthic resources should be considered. The changes in the fish assemblage composition may affect the trophic relationships in the reservoir. Careful measures of the fish introduction and fish stocking densities are required. The overstocking of the planktivorous fishes could result in low water quality through increased microalgal blooms and diminished water transparency. The concurrent stocking of piscivorous fishes may produce more balanced trophic interactions at the bottom of the food webs of the reservoir. Cage culture practice was introduced into Marechal Dutra in 1999 to provide a low cost alternative for increasing fish food to the local population. One of the unpleasant consequences of the eutrophication trend and the formation of cyanobacterial bloom, though seldom, is its association with fish kills (Beveridge, 1987). The first formation of Microcystis bloom and fish kill incidence in Marechal Dutra was registered in January 2000 (Chellappa et al. 2000). Since then, the cyanobacterial species dominance are common but the toxin production has been occasional.

Soares et al (2004) demonstrated the presence of $2.8 \mu \mathrm{g} \mathrm{g}^{-1}$ body weight of microcystins in the liver cells of Tilapia rendalli from the laboratory experimental studies with different feeds including toxic cyanobacteria and indicated the calculated risks involved in aquaculture practices in the ponds. The occurrence of $2.59 \mu \mathrm{g} \mathrm{g}^{-1}$ body weight of microcystin in the liver samples shown in the present study exposed how the local population and reservoir fisheries were vulnerable to the ecotoxicological nature of the freshwater ecosystems of water scarce semiarid North-eastern Brazil. The expanding aquaculture practices in Marechal Dutra, inappropriate use of fish feed, installation of many fish cages in the shallow regions of the reservoir and improper stocking densities of fishes in the cages lead to the eutrophication of the waters and harmful phytoplankton bloom. As a consequence, toxic blooms cause fish kills, contamination of potable water and harmful effects to public the health.

\section{ACKNOWLEDGMENTS}

The authors thank CNPq (National Council for Research and Technological Development of the Ministry of Science and Technology, Brazil) for the financial support (Proc. No. 520921/1995-0).

\section{RESUMO}

Eutrofização em ecossistemas limnéticos tropicais e a conseqüente formação de cianobactérias causam prejuízo econômico à produção pesqueira e efeitos danosos à saúde publica. A mortalidade em massa de peixes devido à produção de cianobactérias tóxicas foi registrada em Dezembro 2003 na Barragem Marechal Dutra, Acari/RN, nordeste Brasileiro. Amostras de fitoplâncton e de peixes foram realizados em dias alternados durante o episódio de mortalidade em massa dos peixes e mensalmente durante Janeiro a Junho de 2004. A toxina das cianobactérias, presente no seston e no fígado dos peixes mortos, foi identificada e quantificada, utilizando o método HPLC padronizado. Os resultados indicaram que a produção de toxinas de Cylindrospermopsis raciborskii e Microcystis aeruginosa foram persistentes por duas semanas e representaram 90\% da composição de espécies de fitoplâncton Os peixes afetados letalmente foram Oreochromis niloticus, Plagioscion squamosissimus, Cichla monoculus, Prochilodus brevis, Hoplias malabaricus e Leporinus friderici. Os níveis de microcistinas variaram entre 0,07 a $8,73 \mu \mathrm{g} \mathrm{L}^{-1}$ nas amostras do seston e 0,01 a $2,59 \mu \mathrm{g} \mathrm{g}^{-1}$ nas amostras no fígado dos peixes, durante o período de aflorescimento. 


\section{REFERENCES}

Azevedo, S. M. F. O.; Evans, W. R.; Carmichael, W. W.; Namikoshi, M. (1994), First Report of Microcystis from a Brazilian isolate of the cyanobacterium, Microcystis aeruginos, J. Appl. Phycol., 6, 261-265.

Baker, P. D.; Humpage, A. R. (1994), Toxicity associated with commonly occurring cyanobacteria in surface waters of Murray-Darling Basin. Aust.Jour.Marine and Freshwat.Res., 45, 773-786.

Best, J. H.; Pflugmacher, S.; Wiegand, C.; Eddy, F. B.; Metclf, J.S.; Codd, G. A. (2002), Effects of enteric bacterial and cyanobacterial lipopolysaccharides, and of microcystin-LR, on glutanione S-transferase activites in zebra fish (Danio rerio). Aquatic Toxicol., 60, 223-231.

Beveridge, M. C. M. (1987), Cage culture, Fishing News Book. Blackwell Science.Publication, Oxford, pp.351.

Bouvy, M.; Falcão D.; Marinho, M.; Pagano, M.; Moura, A. (2000), Occurrence of Cylindrospermopsis (Cyanobacteria) in 39 Brazilian tropical reservoirs during the 1998 drought. Aquat. Microbiol Ecol., 23, 13-27.

Carmichael, W. W. (2001), Health effects of ToxinProducing cyanobacteria, "The CyanoHABs". Human and Ecological risk manag, 7(5), 1359-1401.

Chellappa, N.T.; Costa, M. A.; M., Marinho, I. R.; (2000), Harmful cyanobacterial blooms from semiarid freshwater ecosystems of Northeast Brazil. Australia. Aust Soc Limnology, 38 (2), 45-49.

Chellappa, S.; Chellappa, N. T. (2004), Ecology and reproductive plasticity of the Amazonian cichlid fishes introduced to the freshwater ecosystems of the semi-arid Northeastern Brazil. In-Advances in Fish and Wildlife Ecology and Biology. ed. B. Kaul. Daya Publications, New Delhi, pp.49-57.

Chorus, I.; Bartram, J. (1999), Toxic cyanobacteria in water: a guide to their Public Health Consequences, Monitoring and Management Spon. Lond, UK, pp. 415.

Codd, G. A. (2000), Cyanobacterial toxins, the perception of water quality, and the priorisation of eutrophication control. Ecol engineering., 16, 51-60.

Dellamano-Oliveira, J. M.; Senna, P. A. C.; Taniguchi, G.M. (2003), Limnological characteristics and seasonal changes in density and diversity of Phytoplanktonic community in the Caço Pond, Maranhão State, Brazil. Braz. Arch. Biol. and Technology, Curitiba, 46, 641-651.

Falconer, I. R. (2001), Toxic Cyanobacterial bloom problems in Australian waters: risks and impacts on human health. Phycol., 40, 228-233.

Fitzgerald, D. J.; Cunliffe, D. A.; Burch, M. D. (1999), Development of health alerts for cyanobacteria and related toxins in drinking water in South Australia. Environmental Toxicol., 14, 203-207.
Goltermann, H.L.; Clymo, R.S.; Ohnstad, M.M.M. (1978), Methods of physical and chemical analysis of Freshwaters. Blackwell Sci.Publ, Oxford, pp.213.

Jochimson E. M.; Carmichael, W. W.; Cardo, D.M.; Cookson, S.T.; Holmes, C. M. D.; Antunes, M.B.D.; De Melo, D. A.; Lyra, T. M.; Barreto, V.S.T.; Azevedo, S.M.F.O.; Jarvis, W.R. (1998), Liver failure and death after exposure to microcystins at a hemodialyses center in Brazil. New England J Med., 338, 873-878.

Krishnamurthy, T.; Carmichael, W. W.; Sarver, E. W. (1986), Toxic peptides from freshwater cyanobacteria (blue-green algae). I. Isolation, Purification and characterization of peptides from Microcystis aeruginosa and Anabaena flos-aquae. Toxicon., 24, 865-873.

Lagos, N.; Onodera, H.; Zagastto, H.; Andrinolo, D.; Azevedo, M.F.Q.; Oshima, Y. (1999), The first evidence of paralytic shellfish toxins in the fresh water cyanobacterium Cylindrospermopsis raciborskii, isolated from Brazil. Toxicon., 3, 13571373.

Lee, T.J.; Rhee, G.Y. (1999), Kinetics of growth and death of Anabena flos-acquae (Cyanobacteria) under light limitation and supersaturation. J Phycol., 35, 700-709.

Lund, J. W. G.; Kipling, C.; Le Kren, E.D. (1958), The inverted microscope method of estimating algae number and the statiscal basis of estimating by counting. Hydrobiologia, 11, 143-170.

Magalhães, V. F.; Soares, R. M.; Azevedo, S. M.F. O. (2001), Microcystin contamination in fish from the Jacarepaguá Lagon (Rio de Janeiro, Brazil): ecological implication and human health risk. Toxicon., 39, 1077-1085.

Matthiensen, A.; Yunes, J.S; Codd, G.A. (1999), The occurrence, distribution and toxicity of cyanobacteria in the estuary of Lagoa dos Patos, Rio Grande do Sul. Rev Bras Biol., 59, 361-376.

Moura, A. N.; Dantes, E. W.; Bittewncourt-Oliveira, M.C. (2007), Structure of the phytoplankton in a water supply in the State of Pernamuco-Brazil. Braz. Arch. Biol. and Technology, Curitiba, 50, 645-654.

Porfirio, Z.; Ribeiro, P. M.; Estevan C. S.; Ricardo L. S.; Santana A. E. G. (1999), Hepatosplenomegaly caused by an extract of Cyanobacterium, Microcystis aeruginosa bloom collected in the Manguaba Lagoon, Alagoas- Brazil. Rev Microbiol, 30, 278285.

Quirós, R.; Boveri, M.B. (1999), The relation between fish yield and stocking density in reservoirs from tropical and temperate regions. In-Theoretical Reservoir Ecology and its Applications. (eds. Tundisi, J.G. and Straskraba), M. Backhuys Publishers, The Netherlands, pp.67-83. 
Reynolds, C. S.; Reynolds, S. N.; Munawar, I. F.; Munawar, M. (2000), The regulation of phytoplanckton population dynamics in the worlds largest lakes. Aquat Ecosystems Health management, 3, 1-21.

Soares, R. M.; Magalhães, V. F.; Azevedo, S. M. F. O. (2004), Accumulation and depuration of microcystins in Tilapia rendalli (Cichlidae) under laboratory conditions. Aquatic Toxicol., 70, 1 - 10.
Weah, J.D.; Sheath, R.J. (2003), Freshwater algae of NorthAmerica: Ecology and Classification. Academic Press, London, pp. 918.

Received: November 07, 2005; Revised: January 05, 2007; Accepted: March 23, 2008. 